\title{
Mechanothermal Solid-state Synthesis of Cobalt(II) Ferrite and Determination of its Heat Capacity by MTDSC
}

\author{
Vittorio Berbenni, Chiara Milanese, Giovanna Bruni, Alessandro Girella, \\ and Amedeo Marini \\ CSGI - Unità Operativa di Pavia, Dipartimento di Chimica Fisica della Università di Pavia, \\ Via Taramelli 16, 27100 Pavia, Italy \\ Reprint requests to Dr. Vittorio Berbenni. Fax: 0039-0382-987575. \\ E-mail: vittorio.berbenni@unipv.it
}

Z. Naturforsch. 2010, 65b, 1434 - 1438; received August 13, 2010

Cobalt ferrite $\left(\mathrm{CoFe}_{2} \mathrm{O}_{4}\right)$ has been synthesized by a solid-state mechanothermal process, and
its molar heat capacity has been determined. A stoichiometric mixture of $\mathrm{CoC}_{2} \mathrm{O}_{4} \cdot 2 \mathrm{H}_{2} \mathrm{O}$ and
$\mathrm{FeC}_{2} \mathrm{O}_{4} \cdot 2 \mathrm{H}_{2} \mathrm{O}$ was subjected to a combination of mechanical activation (by high-energy milling)
and thermal activation (by annealing at temperatures between 300 and $700{ }^{\circ} \mathrm{C}$ ). The process was
followed by thermogravimetric analysis and high-temperature X-ray powder diffraction. It has been
shown that $\mathrm{CoFe}_{2} \mathrm{O}_{4}$ forms at all temperatures, though with different degrees of crystallization, while
$\mathrm{Co}_{3} \mathrm{O}_{4}$ and $\mathrm{Fe}_{2} \mathrm{O}_{3}$ are the only products formed when starting from unmilled mixtures. The molar
heat capacity of $\mathrm{CoFe}_{2} \mathrm{O}_{4}$ has been determined in the temperature range $60-400{ }^{\circ} \mathrm{C}$ by MTDSC.
It has been shown that the molar $C_{\mathrm{P}}$ values of $\mathrm{CoFe} \mathrm{O}_{4} \mathrm{O}_{4}$ samples produced at $T \geq 500{ }^{\circ} \mathrm{C}$ are close
to each other while those of the samples produced at 300 and $400{ }^{\circ} \mathrm{C}$ are lower. Furthermore the
$\mathrm{CoFe}_{2} \mathrm{O}_{4}$ samples prepared at $T \geq 500{ }^{\circ} \mathrm{C}$ show very similar microstructures.

Key words: Cobalt Ferrite, Modulated Temperature Differential Scanning Calorimetry (MTDSC), Heat Capacity, Mechanochemistry

\section{Introduction}

Cobalt ferrite belongs to a family of $A \mathrm{Fe}_{2} \mathrm{O}_{4}$-type spinel ferrites where $A$ is a divalent metal. Ferrites have several practical applications as magnetic [1] and refractory materials [2], in medical diagnostics [3] and as catalysts [4]. Several synthetic routes have been devised to prepare $\mathrm{CoFe}_{2} \mathrm{O}_{4}$. Paike et al. [5] synthesized spinel cobalt ferrite by the coprecipitation method using tetramethyl-, tetraethyl-, and tetrabutyl-ammonium hydroxide as precipitating agents. It has been shown that the degree of crystallinity depends on the thermal decomposition temperature and also on the bulkiness of the cation of the occluded organic base. Garcia Cerda et al. [6] prepared a metal-citrate-silica gel from metal salts, citric acid and tetraethylorthosilicate by the sol-gel method. The gel was dried at $100{ }^{\circ} \mathrm{C}$ and then calcined at temperatures between 600 and $1000{ }^{\circ} \mathrm{C}$ to obtain powder samples. Liu et al. [7] prepared $\mathrm{CoFe}_{2} \mathrm{O}_{4}$ nanoplatelets and nanoparticles by a facile hydrothermal treatment of an aqueous solution of cobalt dodecyl sulfate, $\mathrm{FeCl}_{3}$ and $\mathrm{NaOH}$ at $120{ }^{\circ} \mathrm{C}$. Cote et al. [8] produced $\mathrm{CoFe}_{2} \mathrm{O}_{4}$ via the reaction of ferric nitrate and cobalt nitrate with sodium hydroxide. The reaction was carried out in water at temperatures ranging from 200 to $400{ }^{\circ} \mathrm{C}$ and pressures of $25 \mathrm{MPa}$. Yan et al. [9] utilized the combustion method to prepare $\mathrm{CoFe}_{2} \mathrm{O}_{4}$ from a stoichiometric mixture of the nitrates of $\mathrm{Co}$ and $\mathrm{Fe}$ by using glycine as fuel.

Kasapoglu et al. [10] proposed a microwaveassisted combustion synthesis of $\mathrm{CoFe}_{2} \mathrm{O}_{4}$ with urea as a fuel. The synthesis takes only a short time $(\approx 15 \mathrm{~min})$ at $1000{ }^{\circ} \mathrm{C}$. The thermolysis of organic precursors was also used for the synthesis of $\mathrm{CoFe}_{2} \mathrm{O}_{4}$. Randhawa et al. [11] investigated the thermal decomposition of a cobalt tris(malonato)ferrate(III) trihydrate precursor $\mathrm{Co}_{3}\left[\mathrm{Fe}\left(\mathrm{CH}_{2} \mathrm{C}_{2} \mathrm{O}_{4}\right)_{3}\right] \cdot 3 \mathrm{H}_{2} \mathrm{O}$ from ambient temperature to $600{ }^{\circ} \mathrm{C}$ in static atmosphere and succeeded in obtaining $\mathrm{CoFe}_{2} \mathrm{O}_{4}$ at a temperature $\left(380{ }^{\circ} \mathrm{C}\right)$ much lower than that of the ceramic method provided the excess $\mathrm{CoO}$ is removed by treatment with $2 \mathrm{~N}$ nitric acid. Cobalt ferrite nanoparticles have also been prepared by the combination of chemical coprecipitation, mechanical alloying and subsequent heat treatment to reduce milling time and contamination effects [12]. 
The present work reports a solid-state synthesis process of $\mathrm{CoFe}_{2} \mathrm{O}_{4}$ starting from stoichiometric mixtures of $\mathrm{CoC}_{2} \mathrm{O}_{4} \cdot 2 \mathrm{H}_{2} \mathrm{O}$ and $\mathrm{FeC}_{2} \mathrm{O}_{4} \cdot 2 \mathrm{H}_{2} \mathrm{O}$ subjected to a combination of mechanical activation (by high-energy milling) and thermal activation (by annealing at $T$ between 300 and $700{ }^{\circ} \mathrm{C}$ ). Furthermore the molar heat capacity of $\mathrm{CoFe}_{2} \mathrm{O}_{4}$ obtained at the mentioned temperatures has been determined by modulated temperature differential scanning calorimetry (MTDSC) in the temperature range $60-400{ }^{\circ} \mathrm{C}$.

\section{Results and Discussion}

On samples of the mechanically activated mixtures dynamic $\left(10 \mathrm{~K} \mathrm{~min}^{-1}\right)$ simultaneous TG/DSC measurements were performed up to $600{ }^{\circ} \mathrm{C}$ in static air.

Fig. 1 shows the TG/DSC curve of a sample of a milled mixture. The mean mass value attained at the maximum temperature is $M_{600}{ }^{\circ} \mathrm{C}=42.6 \pm 0.1 \%$, significatively lower than the value expected for the formation of a mixture $\mathrm{CoO}-\mathrm{Fe}_{2} \mathrm{O}_{3}$ or of $\mathrm{CoFe}_{2} \mathrm{O}_{4}$ $(43.2 \%)$. This fact can be explained by taking into account that, during high-energy milling, volatile impurities were absorbed by the mixture. These volatile impurities are then released during heating of the milled mixtures. From the experimental mass value attained at $600{ }^{\circ} \mathrm{C}$ it can be easily calculated that $\approx 1.4 \%$ by mass of volatile impurities is absorbed during milling.

The DSC curve shows that a very sharp exothermic DSC peak sets in when the endothermic thermal effect due to the dehydration of the mixture is nearly over. This exothermic peak is over at $\approx 300{ }^{\circ} \mathrm{C}$, and its mean enthalpy is $-2104 \pm 120 \mathrm{~J} \mathrm{~g}^{-1}$ corresponding to $-1158 \pm 66 \mathrm{~kJ}$. The same thermal protocol was applied to samples of the two metal oxalates after they had been subjected to mechanical activa-

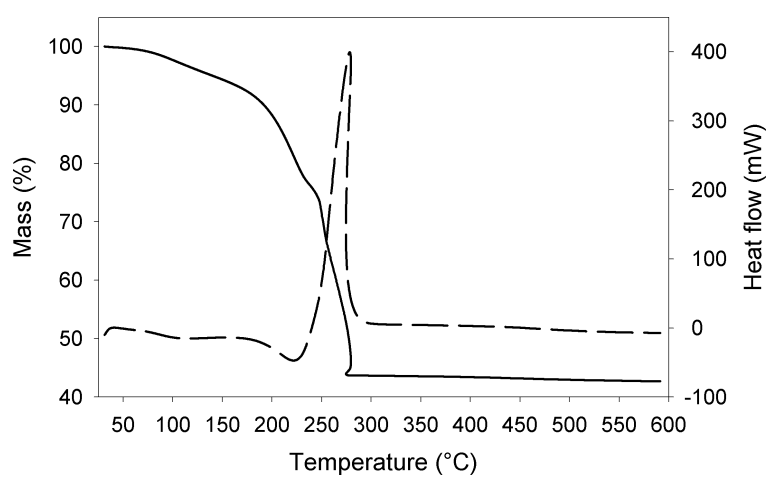

Fig. 1. TG (full line)-DSC (dashed line) of a sample of a milled mixture $\left(10 \mathrm{~K} \mathrm{~min}^{-1}\right.$; static air).

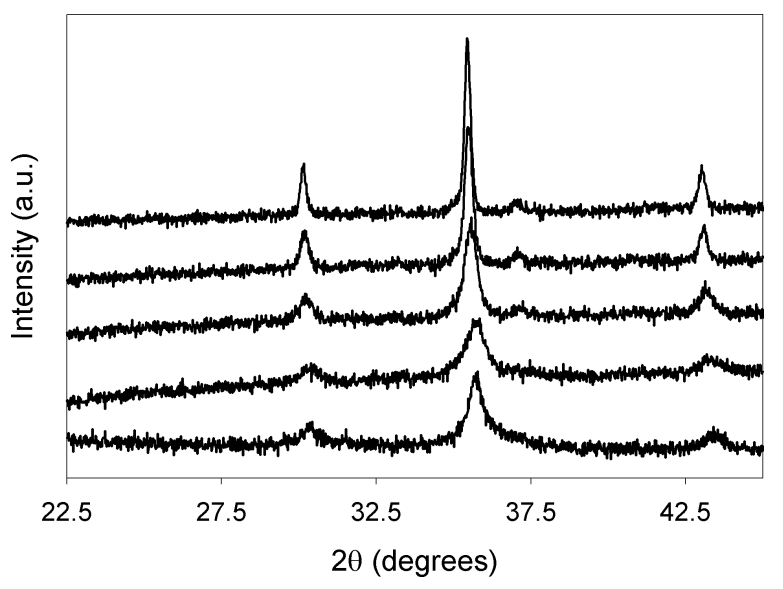

Fig. 2. HT-XRPD powder patterns of a milled mixture heated $\left(10 \mathrm{~K} \mathrm{~min}^{-1}\right.$; static air) at temperatures from $300{ }^{\circ} \mathrm{C}$ (lower curve) up to $700{ }^{\circ} \mathrm{C}$ (upper curve) in steps of $100^{\circ} \mathrm{C}$.

tion by high-energy milling under the same conditions as adopted for the mixture. The DSC thermograms of the two oxalates show, below the decomposition stage, exothermic peaks with associated enthalpies of $-280.7 \pm 5.5 \mathrm{~kJ}[\mathrm{Co}$ (II) oxalate $]$ and $-283.9 \pm 2.9 \mathrm{~kJ}$ [(Fe(II) oxalate], respectively. By taking into account the decomposition enthalpies of the two oxalates, the value expected for the decomposition enthalpy of the mixture is $-848.5 \mathrm{~kJ}$. Confronted with the experimental value of $-1158 \mathrm{~kJ}$, it appears that an enthalpic excess of $\approx-310 \mathrm{~kJ}$ is released during the stage of the decomposition of the mixture that is likely due to the reaction between the formed oxides $\mathrm{CoO}$ and $\mathrm{Fe}_{2} \mathrm{O}_{3}$ to yield $\mathrm{CoFe}_{2} \mathrm{O}_{4}$. Indeed the XRPD powder patterns of the residuals recovered at the end of the TG/DSC measurements performed up to $600{ }^{\circ} \mathrm{C}$ only showed the reflections of $\mathrm{CoFe}_{2} \mathrm{O}_{4}$.

The results of the TG/DSC measurements indicate that $\mathrm{CoFe}_{2} \mathrm{O}_{4}$ begins to form at temperatures as low as $300{ }^{\circ} \mathrm{C}$. Therefore, in order to establish the extent of $\mathrm{CoFe}_{2} \mathrm{O}_{4}$ formation as the temperature increases, an X-ray powder diffraction experiment was carried out on a sample of a milled mixture which was heated $\left(10 \mathrm{~K} \mathrm{~min}^{-1}\right.$, static air) up to $700{ }^{\circ} \mathrm{C}$ and recording the XRPD patterns at 300, 400, 500, 600 and $700{ }^{\circ} \mathrm{C}$. The relevant patterns are shown in Fig. 2.

The peaks characteristic of the constituent oxides $\left(\mathrm{CoO}, \mathrm{Co}_{3} \mathrm{O}_{4}, \mathrm{Fe}_{2} \mathrm{O}_{3}\right)$ are absent in the patterns recorded at all the temperatures, and the patterns only show very broad peaks characteristic of $\mathrm{CoFe}_{2} \mathrm{O}_{4}$. By increasing the temperature, other peaks characteristic 


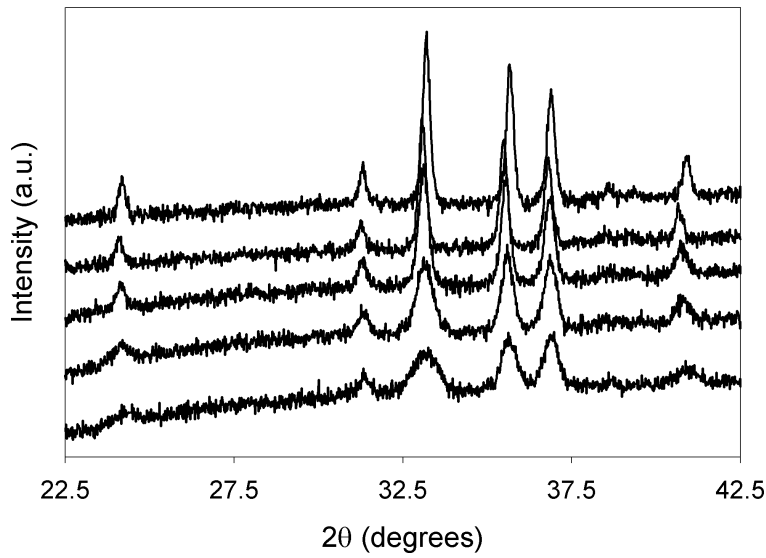

Fig. 3. HT-XRPD powder patterns of a physical mixture heated $\left(10 \mathrm{~K} \mathrm{~min}^{-1}\right.$; static air) at temperatures from $300{ }^{\circ} \mathrm{C}$ (lower curve) up to $700{ }^{\circ} \mathrm{C}$ (upper curve) in steps of $100{ }^{\circ} \mathrm{C}$.

of $\mathrm{CoFe}_{2} \mathrm{O}_{4}$ appear, and their intensity gradually increases. For sake of comparison the same experiment was conducted on a sample of the physical mixture. The results are reported in Fig. 3. Here the only peaks present are those characteristic of the constituent oxides (i.e. $\mathrm{Co}_{3} \mathrm{O}_{4}$ and $\mathrm{Fe}_{2} \mathrm{O}_{3}$ ).

Therefore, on the basis of the results of the HTXRPD diffraction patterns, we attempted to synthesize $\mathrm{CoFe}_{2} \mathrm{O}_{4}$ starting from mixtures mechanically activated and subjecting them to thermal annealing for $8 \mathrm{~h}$ at temperatures of $300,400,500,600$ and $700{ }^{\circ} \mathrm{C}$. The relevant powder patterns are shown in Fig. 4. It can be seen that all the peaks characteristic of $\mathrm{CoFe}_{2} \mathrm{O}_{4}$ are

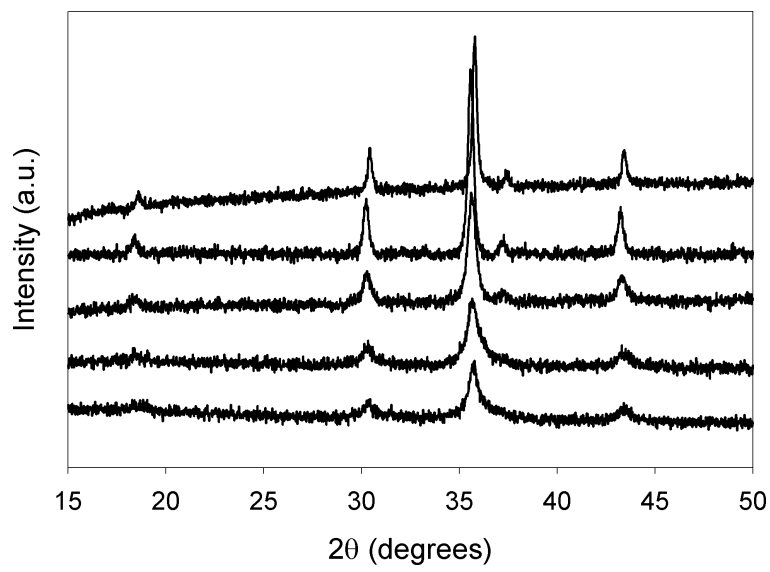

Fig. 4. XRPD powder patterns of samples of a milled mixture heated $\left(10 \mathrm{~K} \mathrm{~min}^{-1}\right.$; static air) for $8 \mathrm{~h}$ at temperatures of from $300{ }^{\circ} \mathrm{C}$ (lower curve) up to $700{ }^{\circ} \mathrm{C}$ (upper curve) in steps of $100{ }^{\circ} \mathrm{C}$.
Table 1 . TG data on mechanically activated samples. $M_{\text {iso,in }}$ and $M_{\mathrm{iso}, \text { fin }}$ are the mass-\% reached respectively at the beginning and at the end of the annealing period $(8 \mathrm{~h})$ at $T_{\text {iso }}$ between 300 and $700{ }^{\circ} \mathrm{C} . M_{1000}{ }^{\circ} \mathrm{C}$ is the mass-\% reached at the end of the ramp at $1000{ }^{\circ} \mathrm{C}$ appended at the isothermal stage.

\begin{tabular}{llll}
\hline$T_{\text {iso }}\left({ }^{\circ} \mathrm{C}\right)$ & $M_{\text {iso,in }}(\%)$ & $M_{\text {iso,fin }}(\%)$ & $M_{1000}{ }^{\circ} \mathrm{C}(\%)$ \\
\hline 300 & $44.0 \pm 0.1$ & $43.6 \pm 0.1$ & $42.3 \pm 0.1$ \\
400 & $44.2 \pm 0.1$ & $43.6 \pm 0.1$ & $42.9 \pm 0.1$ \\
500 & $43.6 \pm 0.1$ & $43.1 \pm 0.1$ & $42.7 \pm 0.1$ \\
600 & $43.1 \pm 0.1$ & $42.5 \pm 0.1$ & $42.4 \pm 0.1$ \\
700 & $42.9 \pm 0.1$ & $42.3 \pm 0.1$ & $42.2 \pm 0.1$ \\
\hline
\end{tabular}

present only in the samples annealed between 500 and $700{ }^{\circ} \mathrm{C}$.

The thermal treatment performed on the milled mixture $\left(8 \mathrm{~h}\right.$ at temperatures between 300 and $\left.700{ }^{\circ} \mathrm{C}\right)$ was followed by recording the mass signal. Furthermore, at the end of the isothermal period, a heating ramp up to $1000{ }^{\circ} \mathrm{C}\left(10 \mathrm{~K} \mathrm{~min}^{-1}\right.$, static air $)$ has been appended. Table 1 reports the $\%$ mass value recorded at the beginning and at the end of the $8 \mathrm{~h}$ isothermal stage $\left(M_{\text {iso,in }}, M_{\text {iso,fin }}\right)$ and at $1000{ }^{\circ} \mathrm{C}\left(M_{1000}{ }^{\circ} \mathrm{C}\right)$. The following considerations can be proposed: a) the mass loss recorded at the isothermal stage is lower at $300{ }^{\circ} \mathrm{C}$ $(-0.4 \%)$ while it is about the same $(\approx-0.6 \%)$ at the other temperatures; b) for $T_{\text {iso }}>300{ }^{\circ} \mathrm{C}$, the mass value attained at the end of the different isothermal periods decreases with increasing $T_{\text {iso }} ;$ c) the values of $M_{\text {iso,fin }}$ become indistinguishable (within the standard deviations) in the case of the samples annealed for $8 \mathrm{~h}$ at 600 and $700{ }^{\circ} \mathrm{C} ; \mathrm{d}$ ) in the case of the mixtures annealed for $8 \mathrm{~h}$ at 600 and at $700{ }^{\circ} \mathrm{C}$, the mean $M_{\text {iso,fin values are }}$ indistinguishable, within the standard deviations, from the mean mass values attained at $1000{ }^{\circ} \mathrm{C}$.

Clearly, the mass loss process is over within the isothermal stage only in the case of the runs performed at 600 and $700{ }^{\circ} \mathrm{C}$ while a mass loss process takes place after the $8 \mathrm{~h}$ isothermal stage performed at $300{ }^{\circ} \mathrm{C}$, $400{ }^{\circ} \mathrm{C}$ and, to a lesser extent, at $500{ }^{\circ} \mathrm{C}$. At first sight such a mass loss process could be the reduction of $\mathrm{Co}_{3} \mathrm{O}_{4}$ to $\mathrm{CoO}$.

However there are two arguments against this hypothesis: a) the mass loss of the mixture annealed for $8 \mathrm{~h}$ at $300{ }^{\circ} \mathrm{C}$ is significantly higher than expected if the reaction $\mathrm{Co}_{3} \mathrm{O}_{4(\mathrm{~s})} \rightarrow 3 \mathrm{CoO}_{(\mathrm{s})}+1 / 2 \mathrm{O}_{2(\mathrm{~g})}$ occurs; b) the XRPD patterns of all the samples annealed at $T_{\text {iso }} \leq 500{ }^{\circ} \mathrm{C}$ do not show evidence of $\mathrm{Co}_{3} \mathrm{O}_{4}$ or of $\mathrm{CoO}$. Another possible explanation of the mass loss process (for $T_{\text {iso }} \leq 500{ }^{\circ} \mathrm{C}$ ) could be the oxidation of the graphite that originates from the carbon deposition 


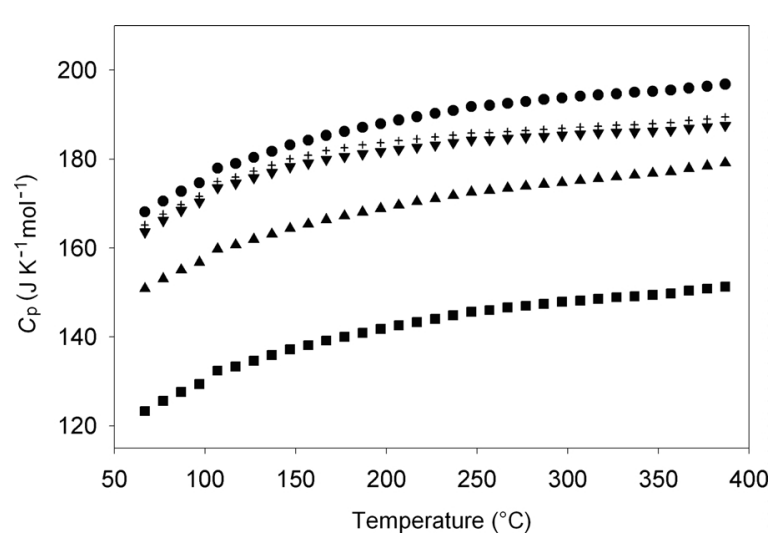

Fig. 5. Molar $C_{\mathrm{P}}$ determined by MTDSC of milled mixtures annealed for $8 \mathrm{~h}$ at $300{ }^{\circ} \mathrm{C}$ (squares); $400{ }^{\circ} \mathrm{C}$ (triangles); $500{ }^{\circ} \mathrm{C}$ (lozenges); $600{ }^{\circ} \mathrm{C}$ (horizontal bars); and $700{ }^{\circ} \mathrm{C}$ (circles).

from the $\mathrm{CO}$ released during the decomposition of the oxalates according to the reaction:

$$
n \mathrm{CO}(\mathrm{g}) \rightarrow n / 2 \mathrm{CO}_{2}(\mathrm{~g})+n / 2 \mathrm{C} \text { (graphite) }
$$

The molar heat capacity of the samples obtained from annealing the milled mixtures has been determined by MTDSC. The values are shown in Fig. 5.

It can be seen that the data of the samples prepared by annealing the activated mixture at temperatures between 500 and $700{ }^{\circ} \mathrm{C}$ are superimposable while the data of the samples annealed at lower temperatures $\left(300\right.$ and $400{ }^{\circ} \mathrm{C}$ ) are lower.

The relevant data have been fitted as a function of temperature by the second order polynomia listed in the following:

$$
\begin{aligned}
& 300{ }^{\circ} \mathrm{C}: C_{\mathrm{p}}=105.16+0.1864 T-0.0002 T^{2} \\
& 400{ }^{\circ} \mathrm{C}: C_{\mathrm{p}}=129.87+0.2056 T-0.0003 T^{2} \\
& 500{ }^{\circ} \mathrm{C}: C_{\mathrm{p}}=153.2+0.1976 T-0.0003 T^{2} \\
& 600{ }^{\circ} \mathrm{C}: C_{\mathrm{p}}=152.47+0.2179 T-0.0003 T^{2} \\
& 700{ }^{\circ} \mathrm{C}: C_{\mathrm{p}}=151.73+0.1971 T-0.0003 T^{2}
\end{aligned}
$$

It can be concluded that the heat capacity data of $\mathrm{CoFe}_{2} \mathrm{O}_{4}$ samples prepared by annealing the milled mixture at temperatures between 500 and $700{ }^{\circ} \mathrm{C}$ can be represented, as a function of temperature, by the relationship:

$$
C_{\mathrm{p}}=(152.5 \pm 0.6)+(0.2042 \pm 0.0097) T-0.0003 T^{2}
$$

The cobalt ferrite samples prepared by the mechanothermal treatment that were annealed at 500,600 and (a)

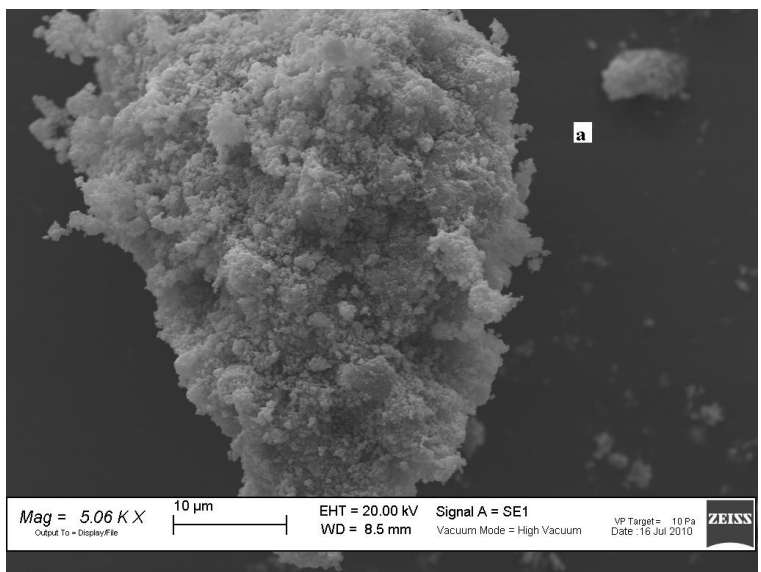

(b)

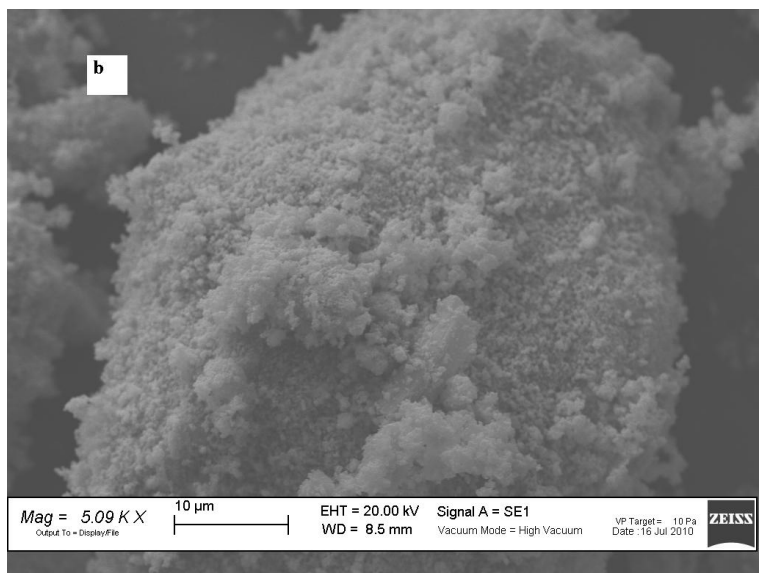

(c)

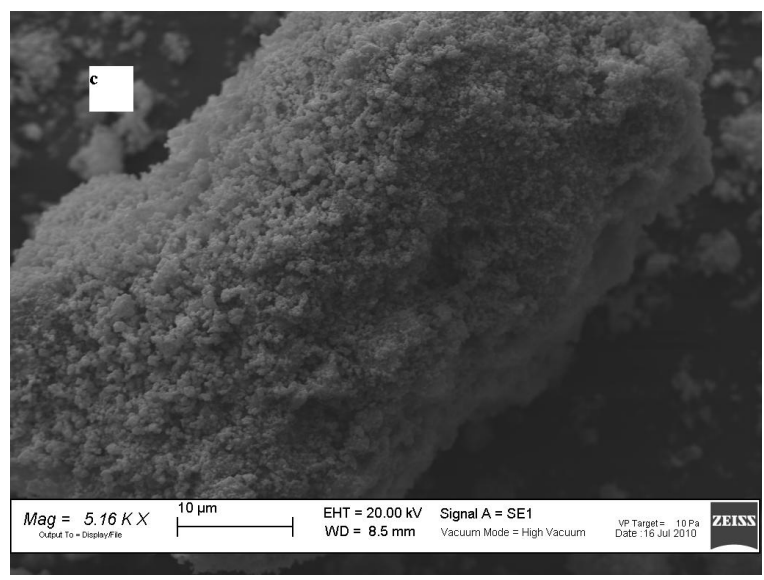

Fig. 6. SEM micrographs taken on a $\mathrm{CoFe}_{2} \mathrm{O}_{4}$ sample prepared from the milled mixture of oxalates of $\mathrm{Co}(\mathrm{II})$ and $\mathrm{Fe}(\mathrm{II})$ subjected to an $8 \mathrm{~h}$ annealing at $500{ }^{\circ} \mathrm{C}$ (a), $600{ }^{\circ} \mathrm{C}$ (b) and $700{ }^{\circ} \mathrm{C}(\mathrm{c})$. 
$700{ }^{\circ} \mathrm{C}$ show, beside very similar $C_{\mathrm{p}}$ values, also a similar microstructure as it can be seen from the SEM micrographs taken under similar conditions (Figs. 6a, $b, c)$.

\section{Conclusion}

It has been demonstrated that $\mathrm{CoFe}_{2} \mathrm{O}_{4}$ can be synthesized starting from a mixture of $\mathrm{Co}$ (II) and $\mathrm{Fe}$ (II) oxalate dihydrates provided it is mechanically activated by high-energy milling before being held isothermally (for $8 \mathrm{~h}$ ) at temperatures as low as $300{ }^{\circ} \mathrm{C}$. Only a mixture of the constituent oxides $\left(\mathrm{Co}_{3} \mathrm{O}_{4}\right.$ and $\left.\mathrm{Fe}_{2} \mathrm{O}_{3}\right)$ is obtained when starting from mixtures where the mechanical activation step has been skipped. Evidence of reaction between the constituent oxides in the milled mixture has also been obtained by DSC and XRPD experiments. Molar heat capacity data on $\mathrm{CoFe}_{2} \mathrm{O}_{4}$ samples prepared by annealing samples of the milled mixture for $8 \mathrm{~h}$ at temperatures of 300, 400, 500, 600 and $700{ }^{\circ} \mathrm{C}$ have been determined: it has been shown that very similar values of $C_{\mathrm{p}}$ as a function of temperature (in the 60-400 ${ }^{\circ} \mathrm{C}$ temperature range) are recorded for the samples prepared by annealing the mixture at $T \geq 500{ }^{\circ} \mathrm{C}$. Also these samples showed, in SEM micrographs, very similar microstructures.

\section{Experimental Section}

The starting chemicals $\left[\mathrm{CoC}_{2} \mathrm{O}_{4} \cdot 2 \mathrm{H}_{2} \mathrm{O}\right.$ (purity 99+\%) and $\mathrm{FeC}_{2} \mathrm{O}_{4} \cdot 2 \mathrm{H}_{2} \mathrm{O}$ (purity 99+\%)] were purchased from Aldrich Chimica (Italy). Physical mixtures of molar ratio $\mathrm{Fe} / \mathrm{Co}=2.0$ were prepared by weighing the appropriate amounts of precursors and by dry milling the powders in an agate mortar. The mechanically activated mixtures were prepared by dry milling lots of $1 \mathrm{~g}$ of the physical mixtures.
The powders were put into zirconia jars $(12.5 \mathrm{~mL})$ of a planetary mill (Pulverisette 7 by Fritsch, Germany) with 4 zirconia balls $(12 \mathrm{~mm}$ diameter; the mass ratio between the milling balls and the sample powder was $7: 1$ ). The mill was operated at $500 \mathrm{rpm}$ (rotation speed) for $8 \mathrm{~h}$.

TG/DSC measurements were performed with a TG-DSC Q600 simultaneous TG/DSC analyzer (TA Instruments Inc., USA). Samples of $\approx 50 \mathrm{mg}$ of the mixtures were placed into alumina cups and heated $\left(10 \mathrm{~K} \mathrm{~min}^{-1}\right.$, air flow $100 \mathrm{~mL}$ $\min ^{-1}$ ) from $25^{\circ} \mathrm{C}$ up to $600{ }^{\circ} \mathrm{C}$.

Samples of both physical and milled mixtures heated at $10 \mathrm{~K} \mathrm{~min}^{-1}$ were examined by XRPD. The XRPD patterns were recorded at $300,400,500,600$, and $700{ }^{\circ} \mathrm{C}$. The relevant patterns were recorded in step scan mode (position-sensitive detector: step width $0.015^{\circ}, 2 \mathrm{~s} / \mathrm{step}, 40 \mathrm{kV}, 40 \mathrm{~mA}, 2 \vartheta=$ $15-50^{\circ}, \mathrm{Cu} K_{\alpha}$ radiation) with an X-ray powder diffractometer (Bruker D5005).

Milled mixture samples were put into alumina boats and heated in air at $10 \mathrm{~K} \mathrm{~min}^{-1}$ up to $300,400,500,600$, and $700{ }^{\circ} \mathrm{C}$ for $8 \mathrm{~h}$; the samples were examined by X-ray powder diffraction. The milled samples were subjected to the same thermal treatment while following the sample mass on a thermobalance (TG Q5000 by TA Instruments Inc., USA).

The specific heat capacity of these very same samples were determined by MTDSC (Q2000, $T_{\text {zero }}$ technology, TA Instruments Inc., USA). The samples $(\approx 30 \mathrm{mg})$ were placed in a hermetically closed aluminum pan and heated at $5 \mathrm{~K}$ $\min ^{-1}$ (nitrogen flow of $50 \mathrm{~mL} \mathrm{~min}{ }^{-1}$, oscillation period $60 \mathrm{~s}$; oscillation amplitude $\pm 0.8{ }^{\circ} \mathrm{C}$ ) whereby the true reversing heat capacity was measured. The data given are the means of at least 15 runs. Before the measurements, the instrument was calibrated under the same experimental conditions with a sapphire disk according to the manufacturer's instructions. A calibration constant of $1.0943 \pm 0.0075$ was obtained. SEM microphotographs were collected on goldsputtered samples with a Zeiss EVO-MA10 scanning electron microscope.
[1] M. Sugimoto, J. Am. Ceram. Soc. 1999, 82, 269-280.

[2] W. G. Wang, M. Mogensen, Solid State Ionics 2005, $176,457-462$.

[3] J. Prodelalova, B. Rittch, A. Spanova, K. Petrova, M. J. Benes, J. Chromatogr. A 2004, 1056, 43 - 48.

[4] T. Mathew, S. Malwadkar, S. Pai, S. Sharanappa, C. Sebastein, C. V. V. Satyanarayana, V. V. Bokade, Catal. Lett. 2003, 91, 217-224.

[5] V. V. Paike, P. S. Niphadkar, V. V. Bokade, P. N. Joshi, J. Am. Ceram. Soc. 2007, 90, 3009-3012.

[6] L. A. Garcia Cerda, S. M. Montemayor, J. Magn. Magn. Mater. 2005, 294, e43-e46.
[7] Q. Liu, J. Sun, H. Long, X. Sun, X. Zhong, Z. Xu, Mater. Chem. Phys. 2008, 108, 269-273.

[8] L. J. Cote, A.S. Teja, A.P. Wilkinson, Z. J. Zhang, Fluid Phase Equilib. 2003, 210, 307 - 317.

[9] C.-H. Yan, Z.-G. Xu, F.-X. Cheng, Z.-M. Wang, L.-D. Sun, C. S. Liao, J.-T. Jia, Solid State Commun. 1999, 111, $287-291$.

[10] N. Kasapoglu, A. Baykal, Y. Köseoglu, M. S. Toprak, Scr. Mater. 2007, 57, $441-444$.

[11] B. S. Randhawa, M. Gupta, M. Kaur, Ceram. Int. 2009, 35, $3521-3524$.

[12] Y. Shi, J. Ding, H. Yin, J. Alloys Comps. 2000, 308, $290-295$. 